\title{
Amor humano y amor divino en la obra de Espinosa
}

\section{Human Love and Divine Love in Spinoza's Work}

\author{
Francisco José Martínez ${ }^{1}$ \\ UNED (España)
}

Recibido: 21-01-18

Aprobado: 02-02-18

\section{Resumen}

El presente trabajo analiza las diversas formas de amor en la obra de Espinosa según los diversos géneros de conocimiento y el tipo de objeto amado, estableciendo una neta contraposición entre el amor pasional a las cosas finitas y el amor intelectual a Dios, entendido como la fuerza vivificante que es causa inmanente de todas las cosas, comparando a nuestro autor con sus antecedentes más inmediatos, especialmente con el judío neoplatónico León Hebreo, el neoestoicismo y Renato Descartes.

Palabras-clave: Espinosa, Descartes, León Hebreo, amor, amor intelectual a Dios, deseo, alegría, pasiones.

\begin{abstract}
The present work analyzes the diverse forms of love in the work of Espinosa according to the different genres of knowledge and the type of object loved, establishing a clear contrast between the passionate love of finite things and the intellectual love of God, understood as the force vivifying, which is the

\footnotetext{
${ }^{1}$ (fjmarmar@fsof.uned.es). Catedrático de Metafísica de la UNED, Presidente del Seminario Spinoza, Coordinador de la Sección de Pensamiento de la Fundación de Investigaciones Marxistas. Sus líneas de investigación son el pensamiento postestructuralista francés, especialmente Deleuze y Foucault; Espinosa y el barroco; y el marxismo crítico. Sus últimas publicaciones son: Autoconstitución y libertad. Ontología y política en Spinoza 2007; Hacia una era post-mediática. Ontología, política y ecología en la obra de Félix Guattari, 2008; Próspero en el laberinto. Las dos caras del Barroco, 2014; Pensar hoy: una ontología del presente, 2015; artículos y capítulos de libros: "Identidad nacional y republicanismo en Espinosa",2005; "La contemporaneidad de Espinosa: resistir a la crisis", 2008; "Normatividad y empiria: el recurso a los ejemplos históricos en el Tratado Político", 2008; "La democracia en Espinosa, anomalía en su siglo", 2012; "Desiderium y Cupiditas: la esencia humana según Spinoza", 2017.
} 
immanent cause of all things, comparing our author with his more immediate antecedents, especially with the Neo-Platonic Jew Leo Hebreo, the neoestoicism and Renato Descartes.

Key-words: Espinosa, Descartes, León Hebreo, Love, Intellectual Love to God, Desire, Joy, Passions.

No women, no cry (Bob Marley).

Lo que no se ama no engendra nunca disputas, ni tristeza si se pierde, ni envidia cuando otro lo posee, ni temor, ni odio, en una palabra, ninguna conmoción del alma. Pero ocurre todo esto cuando amamos cosas perecederas [...] En cambio, el amor por una cosa eterna e infinita alimenta el alma de pura alegría y la libra de toda tristeza; lo que es muy de desear y muy digno de ser buscado con todas nuestras fuerzas. (Espinosa, $\mathrm{TRE}^{2} \mathrm{I}, \S \S 9-10$ )

\section{Definición de la noción de amor}

El amor es una noción central en la obra de Espinosa ya que está en la encrucijada de numerosas problemáticas que se cruzan en dicha obra. Aunque no es uno de los afectos fundamentales, al contrario que para Descartes ${ }^{3}$, el amor está en la conexión entre su noción de hombre y su noción de Dios; el amor se encuentra en relación con los tres géneros de conocimiento: la imaginación se relaciona con el amor bestial y el humano, mientras que la razón y la ciencia intuitiva se relacionan con el amor a Dios; dicha noción se encuentra también involucrada en la tensión que se da en su obra entre una concepción afirmativa del deseo como cupiditas y una noción negativa del mismo como desiderium; es un elemento clave para poder decidir sobre el eventual papel del platonismo y el neoplatonismo en su obra ${ }^{4}$; es también central para explicar las conexiones

\footnotetext{
2 Spinoza, Tratado de la reforma del entendimiento/Principios de filosofía de Descartes/ Pensamientos metafisicos, Madrid, Alianza, 1988, TRE.

${ }^{3}$ Descartes considera pasiones primitivas la admiración, el amor y el odio, la alegría, la tristeza y el deseo (Cf. Passions de l'âme, II, artículo LXIX, París, 1649, p. 94, disponible en Gallica) y Espinosa retoma en parte esta clasificación en el TB, aunque no en la Etica.

${ }^{4}$ Espinosa mantiene una tensión antiplatónica a lo largo de su obra, aunque al principio coquetea con cierto neoplatonismo, especialmente el de León Hebreo, del que siempre le separó su apuesta por la inmanencia frente a la apuesta emanatista de los neoplatónicos. (Cf. Carl Gebhardt, "Spinoza und der Platonismus" en Cronicum Spinozanum, tomo I, Amsterdam,1921, pp. 178-234; Leon Brunschvig, "Le platonisme de Spinoza" en Cronicum Spinozanum, tomo III, Amsterdam,1923, pp.253-268, quien afirma que fue el influjo dela geometría analítica de Descartes lo que le permitió pasar a Espinosa de su neoplatonismo inicial al platonismo propiamente dicho basado en las matemáticas; Ulysses Pinheiro, "A presença do neoplatonismo de Leão Hebreu na Etica de Spinoza", Kléos no 19, 2015, pp. 227 246, disponible en internet). Por su parte, Negri insiste en este neoplatonismo de cuño renacentista, solidario con la utopía del mercado capitalista naciente, del primer Espinosa para decir que el Espinosa maduro lo convierte en un pensamiento de la superficie, transfigurando dicho neoplatonismo en una filosofía materialista y no dialéctica de la apropiación, en un proyecto de autoconstitución consciente
} 
entre el conocimiento y los afectos en el Espinosa del libro V de la Etica, centrada en la paradójica noción de amor dei intellectualis ${ }^{5}$; está en el centro de la recepción espinosiana de la tradición hebrea, tanto medieval (Crescas, Maimónides), como renacentista (León Hebreo) ; también es clave para entender las posibles concomitancias entre la obra de Bruno y la de nuestro autor; por último, la importancia de esta noción en su obra la relaciona con el ordo amoris ${ }^{6}$ cristiano, cuyo origen se puede rastrear en Pablo y Agustín. Por todas estas razones es esencial plantear dicha noción en toda su riqueza y diversidad de matices.

Frente a la idea tradicional que sitúa al cuerpo como origen de las pasiones, para Espinosa, ya desde el $\mathrm{TB}^{7}$, el origen de las pasiones está en el conocimiento y más concretamente en la opinión y la imaginación. Aplicando estas ideas al amor vemos como el amor se declina de muchas maneras en la obra de Espinosa. Podemos establecer una clasificación de los diversos tipos de amor conjugando los criterios del objeto amado y del modo de conocimiento dominante en cada caso. Tenemos, por tanto, una matriz de dos por tres, lo que nos da seis posibles modos de amor: Según el objeto amado podemos hablar, siguiendo al Tratado Breve, de amor a cosas perecederas y amor a cosas imperecederas, amalgamando en este último tipo a las cosas imperecederas por su causa, los modos infinitos, y la cosa eterna e imperecedera por su propia fuerza y potencia, es decir, Dios o la Verdad (TB, II, cap. V, 2, p. 110). Según el modo de conocimiento, tenemos el amor pasional, basado en la imaginación, el amor basado en la razón y el amor basado en la ciencia intuitiva, el amor dei intellectualis. Al combinar los dos criterios tenemos cinco tipos posibles de amor, ya que no parece posible tener un amor imaginativo

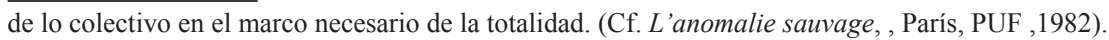

${ }^{5}$ Esta noción se debe a Descartes que la define en su carta a Chanut del 1 de febrero de 1647 en René Descartes, Correspondencia con Isabel de Bohemia y otras cartas, Barcelona, Alba Editorial, 1999, pp. 232-246. (Cf. Saverio Ansaldi, "Un nouvel art d'aimer. Descartes, Léon l'Hébreu et Spinoza" en Chantal Jaquet, Pascal Séverac, Ariel Suhamy, Spinoza, philosophe de l'amour, SaintEtienne, Publications de l'Université de Saint- Etienne, 2005, pp.23-40.

${ }^{6}$ Sobre esta noción se puede consultar Max Scheler, Ordo amoris, Madrid, Caparrós Editores, 1996 y Remo Bodei, Ordo amoris. Conflictos terrenos y felicidad terrestre, Valladolid, Cuatro ediciones, 1998. Ambos autores consideran el ordo amoris, de raigambre agustiniana, como un orden divino y ambos destacan la importancia del amor en el hombre frente al mero conocimiento, así como la necesidad no tanto de reprimir las pasiones como de, más bien, transmutarlas en una tendencia hacia Dios. La diferencia esencial con Espinosa es la noción de un Dios trascendente y voluntarista frente a un Dios inmanente y necesitarista. Bernard Rousset sitúa a Espinosa en la charnela entre los monismos neoplatónicos que son sus antecedentes y los monismos materialistas que le siguen, y distingue una Etica A ya escrita en 1665 y una Etica B que fue la definitiva. La Etica A conservaría algunos rasgos neoplatónicos y a esta Etica inicial pertenecería gran parte del libro V, mientras que los libros III y IV y la primera mitad de V presentan un estilo menos retórico, más sobrio, más 'materialista', en la línea de Hobbes, y desarrollan la teoría del conatus. Mientras que el enfoque de Etica A es esencialmente ontológico y teológico, participativo, el enfoque de Etica B es más antropológico y relacional, estableciendo una dinámica de los afectos y una dinámica social. (Cf. Bernard Préposiet, "La premiére 'Ethique'. Méthode et perspectives" en Bernard Préposiet, L'inmanence et le salut. Regards spinozistas, Paris, Kimé, 2000, p. 92).

7 Spinoza, Tratado Breve, Madrid, Alianza, 1990, TB.

Araucaria. Revista Iberoamericana de Filosofía, Política y Humanidades, año 20, n 39. Primer semestre de 2018. Pp. 271-296. ISSN 1575-6823 e-ISSN 2340-2199 doi: 10.12795/araucaria.2018.i39.13 
de Dios, porque Dios no puede captarse mediante la imaginación. Tenemos, pues, como extremos opuestos, el amor pasional, amor de cosas perecederas basado en la imaginación y el amor dei intellectualis, amor a Dios basado en la ciencia intuitiva y entre ellos, dos tipos de amor racional, a las cosas perecederas y a Dios mismo, aunque para Espinosa estos tipos de amor racional son problemáticos ya que se basan en la deducción y en lo que hay de común entre las cosas y, por ello, no son propiamente amores que suelen considerarse referidos a las cosas singulares; y un tipo de amor de cosas perecederas pero basado en la ciencia intuitiva y que sería parte o modo del amor dei intellectualis. Mientras que el amor a las cosas singulares depende de la opinión y la imaginación y es una pasión, y por tanto puede engendrar pesar, el amor a Dios es una acción y además protege al alma de las perturbaciones debidas a las pasiones ${ }^{8}$.

Para empezar, conviene recordar que Espinosa ni en su vida ni en su pensamiento fue ascético. Reconoce que los placeres del cuerpo y los del espíritu no son algo de lo que ni siquiera el sabio tenga que prescindir. Contra lo que a veces se dice Espinosa no era un sabio recluido en su biblioteca. Siempre vivió en conexión con los centros políticos, económicos y culturales de su país. Su cultura era urbana y rechazó siempre el 'desprecio de corte y alabanza de aldea' que algunos cultivaban en su época. Nuestro autor condenó explícitamente la retirada del mundo, tanto en su versión religiosa, como en la versión profana cultivada por la poesía pastoril y bucólica y mantuvo una red amplia de amigos tanto presenciales como a distancia, a través del intercambio epistolar. A partir de su idea de los cuerpos como compuestos de muchas componentes, y por tanto con muchas necesidades, defendía que el individuo tenía que mantener una amplia red de relaciones con las cosas exteriores, y especialmente con los demás hombres, para satisfacer sus necesidades físicas y espirituales. De las tres clases de bienes que se distinguían en su época, los deleitables, los útiles y los honestos, él no despreciaba ninguno, aunque los jerarquizaba de forma conveniente. En su teoría y en su vida no despreciaba ningún tipo de placer ya que, desde el punto de vista ontológico, todos tenían y proporcionaban cierto grado de perfección, y desde el punto de vista axiológico ninguno era condenable, en sí mismo considerado. Ahora bien, dada la limitación de la vida humana, Espinosa pensaba que no todos los placeres eran iguales, ya que algunos conllevaban males añadidos y todos podían ser superados en perfección por algún otro.

\footnotetext{
8 Respecto de la contraposición entre el amor humano y el amor divino se puede consultar el espléndido trabajo de Pilar Benito, "La potencia humana del amor transformada en el amor intelectual de Dios “ en Ma. Luisa de la Cámara y Julián Carvajal (eds): Spinoza y la Antropología en la Modernidad, Hildesheim, Georg Olms Verlag, 2017, pp. 193-202, así como su monumental obra Baruj Spinoza. Una nueva ética para la liberación humana, Madrid, Biblioteca Nueva, 2015.

9 "Ríanse, pues, cuanto quieran, de las cosas humanas los satíricos y detéstenlas los teólogos y alaben los melancólicos cuanto puedan, la vida inculta y agreste, y desprecien a los hombres y admiren a los brutos." (E IV,35, esc., p. 206).
} 
Su obra primeriza, dedicada a la reforma del entendimiento, es el relato de la búsqueda entre los diversos bienes para definir, y luego intentar conseguir, un bien que no pudiera ser superado en perfección por ningún otro y que no conllevara aparejado ningún dolor. Nuestro autor examina los bienes que se consideran habitualmente, a saber, la riqueza, el honor y el placer, y piensa que dedicarse solo a ellos es un obstáculo para dedicarse a cualquier otra cosa y además muchas veces dichos bienes son incompatibles entre sí. Mediante la meditación nuestro autor se da cuenta de que si se dedicara a la reflexión "dejaría males ciertos por un bien cierto". Los males se relacionan con el amor que se profesa a dicho tipo de bienes, ya que lo que no se ama no proporciona dolor. En cambio, si se ama una "cosa eterna e infinita "el alma siente "una alegría totalmente pura y libre de tristeza". Pero el realismo de Espinosa le lleva a ser consciente de que por mucho que captara las cosas con toda claridad ,"no por ello podría deponer toda avaricia, todo deseo sexual y toda gloria", aunque mientras se esforzaba en reflexionar su alma se encontraba libre de dichos afectos, lo que le permitió darse cuenta de forma paulatina de que "esos males no eran de tal índole que resistieran a todo remedio"; más aún, la reflexión le llevó a considerar que el esforzarse en conseguir placer, dinero y gloria estorba solo en la medida en que se los busca en sí mismos y no como medio para otras cosas, mientras que "si se buscan como medios, ya tienen una medida y no estorban en absoluto, sino que, por el contrario, ayudarán mucho al fin por el que se buscan “. Por lo tanto, estos bienes perecederos no son malos en sí mismos, sino solo si se absolutizan y se buscan como bien supremo; como medios, aparte de ser ineliminables, pueden ser incluso convenientes.

De todas formas, Espinosa es consciente de que el placer (Titillatio) puede tener exceso y ser malo y de que también el amor y el deseo pueden tener exceso. En efecto, el placer en cuanto referido al cuerpo hace que algunas de las partes de éste se vean afectadas más que las demás, y si este afecto es demasiado fuerte puede superar las demás acciones del cuerpo y evitar que dicho cuerpo sea afectado de otros modos ( $E^{10}$ IV, 43, p. 213). De nuevo el problema del placer no está en sí mismo, sino en su parcialidad y en su fijación en una sola cosa o aspecto de la realidad que impiden la pluralidad de relaciones y afecciones del cuerpo con el resto de las cosas. Como el amor es un tipo de placer se le puede aplicar lo dicho respecto de éste. La fijación en una sola cosa llega a producir una especie de delirio: "no menos locos se cree que están quienes arden en amor y pasan las noches y los días soñando solo en su amante o en la meretriz..." (E IV, 44, esc., p. 214). De todas formas, el amor siempre es preferible al odio e incluso puede servir de antídoto al mismo, y, por ello, los hombres que viven bajo la guía de la razón se esfuerzan en compensar el odio que reciben de los demás mediante el amor o la generosidad (E IV, 46, p. 215).

\footnotetext{
${ }^{10}$ Baruj Spinoza, Etica demostrada según el orden geométrico, Madrid, Trotta, 2000, E.
} 
Espinosa dice que hay un modelo de naturaleza humana más firme que la suya y que todo lo que lleve hacia ella es un bien verdadero y el sumo bien consiste en alcanzar dicha naturaleza. La obtención de esa naturaleza humana modélica no es una tarea del individuo aislado, como para los estoicos y neoestoicos, sino de cada individuo en colaboración con los demás individuos, especialmente con aquellos cuyo entendimiento y deseos coincidan con los míos, es decir, que es preciso para conseguir la felicidad asociada a la obtención de esa naturaleza humana constituir una sociedad que facilite la obtención con facilidad y seguridad a la mayor parte de individuos posibles. Como vemos aquí la búsqueda de la perfección y la felicidad asociada a ella no es un proyecto del sabio aislado sino que es un proyecto directamente político. La naturaleza humana concebida aquí por nuestro autor se basa en "el conocimiento de la unión que la mantiene con toda la Naturaleza” (TRE, §1, pp. 75-81). Y dado que posteriormente identificará a Dios con la Naturaleza, el bien sumo que define la naturaleza humana será el amor intelectual a Dios, es decir, una relación cognoscitiva y afectiva con el manantial fundante del conjunto de la realidad, el elemento vivificador del universo, o sea con Dios como natura naturans. La felicidad asociada a la obtención de este bien máximo y definitivo la denomina, acudiendo a nomenclatura religiosa, beatitud o gloria y resalta en ella sus aspectos cognitivos y afectivos.

En el Tratado Breve Espinosa habla también de 'la idea de un hombre perfecto' y de que tenemos que investigar en nosotros mismos para ver si "existe en nosotros algún medio para alcanzar tal perfección” (TB, II, 4, §5 y $§ 8$ p. 108). La perfección del hombre consiste en su capacidad de conocer y su conocimiento es tanto más perfecto cuanto más perfección tiene su objeto, por lo tanto, "el hombre más perfecto es aquel que se une a Dios (que es el ser perfectísimo) y goza así de él” (TB, II, 4, §10 p. 109). Por bien, pues, se entiende lo que consideramos que nos aproxima a dicho modelo de la naturaleza humana y por mal lo que nos aleja de dicho modelo; de igual manera, los hombres son más o menos perfectos según se aproximen o se alejen de dicho modelo (E IV, prólogo, p. 185). Por todo lo anterior podemos comprender que los reparos que Espinosa ponía a los bienes inferiores, los deleitables y útiles frente a los honestos, no era un desprecio por los mismos sino la consideración de que la dedicación de energías y tiempo a la consecución de estos bienes inferiores obstaculizaba la consecución del bien supremo.

Este bien supremo tiene que ser accesible a todos y eso es lo que afirma Espinosa en el libro IV de la Etica donde dice "el sumo bien de quienes persiguen la virtud es común a todos, y todos pueden gozar igualmente de él" (E IV, 36, p. 206). De igual manera, el bien que apetece el virtuoso lo desea también para los demás hombres y tanto más cuanto mayor sea su conocimiento de Dios (E IV, 37 , p. 207. Esto sucede cuando el individuo actúa bajo el imperio de la razón y 
busca un bien imperecedero, ya que si opera bajo la influencia de los afectos y se centra en bienes perecederos que solo pueden ser gozados por uno, entonces el que varios amen la misma cosa producirá conflictos entre ellos.

Aplicando todo esto al caso del amor humano podemos decir que se puede detectar una paradoja en el planteamiento espinosiano. Por un lado, se defiende que el individuo es tanto más perfecto cuantas más relaciones tiene con las cosas exteriores, especialmente con los hombres y todavía más con los hombres sabios. En estas relaciones se experimenta la necesidad, y por lo tanto la dependencia, de las mismas. En el libro IV de la Etica Espinosa nos recuerda que "nunca podremos conseguir que no necesitemos nada exterior para conservar nuestro ser y que vivamos sin tener intercambio alguno con las cosas que están fuera de nosotros", ya que "se dan fuera de nosotros muchas cosas que nos son útiles y que, por tanto, deben ser apetecidas" (E IV, 18, esc., p. 197). De igual manera, lo que dispone al cuerpo humano para que pueda ser afectado de muchos modos o lo hace capaz de afectar de muchos modos a los cuerpos exteriores es útil para el hombre (E IV, 38, p. 210). El inconveniente de estas relaciones es que suelen ser pasiones, ya que no somos causas adecuadas de las mismas, porque dependemos de las cosas exteriores, lo que hace que dichas relaciones no se puedan explicar solo por nosotros mismos, es decir no nos tienen solo a nosotros mismos como causas.

Espinosa no es un estoico ni un neoestoico, no defiende el elitismo de los sabios separados de los ignaros, reconoce que todo hombre hasta el más sabio necesita a sus semejantes, incluso a los no sabios, y que es mejor una compañía, aunque no sea perfecta que la soledad. Pero al mismo tiempo en su obra aparece que el deseo que constituye la esencia del hombre, la cupiditas, es algo afirmativo y positivo que no depende, como el desiderium, de las cosas exteriores. La sabiduría consiste en sublimar el desiderium de las cosas externas en una cupiditas afirmativa autónoma. Con lo que parece que se daría una contradicción entre la idea de un hombre en una estrecha dependencia de las cosas exteriores a través de una amplia e intensa red de relaciones y la idea de un sabio que comparte con el sabio estoico su independencia respecto de las vicisitudes externas y su autonomía y suficiencia.

La antropología espinosiana se sitúa entre las antropologías pesimistas de raíz judeo-cristiana que parten de la idea de un hombre dañado de forma irreversible por el pecado y que necesita la gracia divina para poder conocer, ser bueno y sobre todo para salvarse y, las antropologías elitistas estoicas y epicúreas que tenían como ideal un sabio apático, indiferente a las cosas mundanas. El individuo espinosiano no es un ser desdichado que se mueve agitado por las cosas externas que lo llevan a su antojo y ante las cuales muestra su impotencia, solo redimible gracias a la gracia divina, pero tampoco es un individuo absoluto en el sentido de no dependiente de nada externo. 
El individuo espinosiano tiene necesidades y trata de satisfacerlas, a la vez trata de que sus deseos (desiderium) no lo atormenten demasiado e intenta a través del conocimiento de sus deseos y de los objetos de sus deseos purificar ese desiderium transformándolo en cupiditas, potenciando la actividad y disminuyendo la pasividad en sus actuaciones. Intentando aumentar los aspectos activos y disminuir los pasivos en su obrar, de forma que cada vez sea una causa más adecuada que explique cada vez más sus acciones solo a partir de sí mismo, disminuyendo el papel de las cosas exteriores en su actividad. Pero dado que no somos dioses, nunca podremos ser completamente causas adecuadas de nuestras acciones. Siempre en las mismas las cosas exteriores tendrán un papel ineliminable. Se trata pues de desarrollar un arte del buen encuentro que nos permita ir encontrando aquellas cosas exteriores que potencien nuestro conatus, es decir que sean causa de alegría, y evitar aquellas cosas que limiten o reduzcan nuestra potencia y por eso sean causa de tristeza. Pero no podemos pasar sin las cosas exteriores por lo que cierta dependencia y pasividad son ineliminables, hasta para los más sabios.

Por otra parte, Espinosa da dos definiciones del amor, una en el TB, según la cual "el amor, no es otra cosa que gozar de una cosa y unirse con ella"11 (TB,

${ }^{11}$ Esta definición del amor coincide casi exactamente con la dada por León Hebreo (León Abarbanel) en sus Diálogos de amor, libro que Espinosa tenía en su biblioteca en una traducción española. Para el judío de origen portugués "el amor es el afecto voluntario de gozar con unión de la cosa que hemos considerado buena" (Cf. León Hebreo, Diálogos de amor, Madrid, Alianza, 2002, p. 49). Aquí hay dos cosas que rechazará nuestro autor, el carácter voluntario del amor y que sea la unión con la cosa amada la que defina el amor; para Espinosa el deseo de unión con la cosa no es la definición del amor sino una de sus propiedades. En la definición que da del amor al final del libro III Espinosa dice que para él la voluntad no es el decreto libre sino "la complacencia que hay en el amante por la presencia de la cosa amada, por la cual es corroborada o al menos fomentada la alegría del amante" (E III def. 6, p. 171). Nuestro autor identifica el entendimiento y la voluntad (E II, 49, p. 115), el intelectualismo y el voluntarismo medievales: para él no se da primero el conocimiento y luego la voluntad, sino que cada volición singular coincide con la idea de la cosa querida y además la voluntad no es libre sino determinada por una causa que se inserta en una serie causal indefinida (E II, 48, p. 114). La necesidad de amor en el TB hace que en el mismo impere una 'ontología de la debilidad', paralela a la de León Hebreo que en las obras maduras se sustituye por una 'ontología de la potencia'. Se pasa de la idea de una comunidad universal de amor que anima todos los seres de corte neoplatónico a un mecanicismo universal de corte galileano y cartesiano. (Cf. Chantal Jaquet, "L'essence de l'amour dans les Dialogues d'amour de Leon L'Hébreu et dans le Court Traité" en Severio Ansaldi (dir.), Spinoza et la renaissance, París, PUPS, 2007, p. 43). También Moreau insiste en este punto: la ontología del TB es una 'ontología negativa', según la cual somos tan débiles que tenemos que sacar la fuerza de otra cosa, precisamente de los objetos que amamos. La antropología del conatus sustituirá en la Etica esta ontología de la debilidad. (Cf. Pierre François Moreau, "L' amour dans le Traité de la réforme de l'entendement" en Chantal Jaquet, Pascal Séverac, Ariel Suhamy, Spinoza, philosophe de l'amour, Saint-Etienne, Publications de l' Université de Saint- Etienne 2005, p. 18).

Se encuentra una definición semejante en la obra de Ramón Sabiuda o Sabunde judío español del siglo XV, nacido en Barcelona, y conocido por la Apología que Montaigne hizo de él en sus Ensayos. Para Sabiuda el amor es voluntario, "une al amante con lo amado y cambia, convierte y transforma al amante en la persona amada". La editora de la principal obra de Sabiuda, su Tratado del amor de las criaturas, Madrid, Tecnos, 1998, Ana Martínez Arancón relaciona la obra del judío con la de Pascal y la de Espinosa (cf. El Prólogo al Tratado de Sabiuda,pp.52-53) y dice que se da un paralelismo entre el 
II, cap. V, 1, p.109) y otra en la Etica que lo define como "la alegría acompañada de la idea de una causa exterior" (E III, 13 e, p.132). En la primera definición se hace hincapié en la unión con el objeto amado y el gozo que se obtiene de dicha unión, mientras que en la segunda no se alude a la unión con el objeto amado, sino que se pone el acento en el paso a una perfección mayor (alegría) concomitante con la idea de una causa exterior. En esta segunda definición no se exige la unión efectiva con el objeto amado, sino que basta la conexión de su idea con el aumento de la perfección del amante, aumento que no se vincula tampoco necesariamente de forma causal con el objeto amado, lo que hace que podemos amar cosas que no producen realmente el aumento de perfección que supone la alegría sino solo de manera circunstancial por proximidad o semejanza ${ }^{12}$. De una definición a la otra se produce una intelectualización del afecto y una gradación del mismo. Ya no se trata de la felicidad producida por la unión o la falta de unión con el objeto, sino de un simple aumento de perfección. Por otra parte, pasamos del todo o nada de la unión y del gozo resultante, al aumento o disminución de la propia perfección, es decir se pasa de una consideración absoluta a una consideración relativa, cuantitativa.

El amor, en tanto que modo del pensar, al igual que el deseo y otros modos de pensar, tiene una estructura intencional, es decir, no se da en la mente sin la idea de la cosa amada, aunque dicha idea se puede dar sin ningún otro modo de pensar (E II Ax 3, p. 78).

En el libro III de la Etica Espinosa despliega una concepción de los afectos que se puede aplicar también al amor, un amor ya definido aquí como "la alegría

objetivo de la Etica y el de la obra de Sabiuda,a saber, demostrar por métodos científicos las verdades morales, el método de Sabiuda es la lógica y el de Espinosa es la geometría. Respecto del amor, para Sabiuda un amor solo puede ser vencido por otro amor más grande y para Espinosa una pasión solo puede ser vencida por otra pasión más fuerte; además, tanto uno como otro defienden la estructura metonímica del amor, es decir su propagación de una cosa a otra por contigüidad; ambos despliegan una filosofía de la alegría y la felicidad; ambos identifican la felicidad con el amor, especialmente con el amor a Dios. Todas estas cercanías son ciertas, lo único que hay que reprochar a la editora es que considera que en la unión con Dios el individuo para Espinosa se anega en dicha unión mientras que para Sabiuda el individuo mantiene su propia individualidad. No hay disolución mística del individuo en la unión amorosa con Dios, para nuestro autor, sino máxima afirmación de su individualidad. Las conexiones de Espinosa con el pensamiento judío de origen ibérico, tanto medieval como renacentista, son claras y evidentes, lo que no obsta para que su inserción en dicha tradición, como en el resto de tradiciones en las que se inserta, como el estoicismo, el cartesianismo, etc., sea siempre crítica y selectiva y además les aplica la paleonímia, es decir, el mantenimiento de las palabras clásicas dándoles un sentido inédito y original que subvierte el sentido tradicional de dichos términos. Espinosa no surge ex novo, pero, como todos los genios, introduce una novedad radical en el seno de las tradiciones intelectuales y culturales de las que se alimenta y a las que transforma. En esa remodelación de las tradiciones clásicas juega un papel esencial la recepción de la ciencia moderna, y más específicamente la física galileana y la nueva ciencia de la vida, como nos recuerda sagazmente P. F. Moreau en "Le vocabulaire psychologique de Spinoza et le problème de sa traduction", disponible en la web de la Association des amis de Spinoza.

${ }^{12}$ Cf. Ariel Suhamy, “Essence, propriété et espéces d'amour dans 1'Ethique” en Chantal Jaquet, Pascal Séverac, Ariel Suhamy, Spinoza, philosophe de l'amour, , Saint-Etienne, Publications de l’Université de Saint- Etienne 2005, pp.77-94. 
acompañada de la idea de una causa exterior" (E III, 13, esc. P.136). El amor es una alegría, es decir, "la pasión por la que el alma pasa a una perfección mayor" (E III, 11, esc. 134), alegría acompañada (concomitante), no tanto causada, por la idea de una causa exterior. Es decir, el amor remite a algo externo a lo que atribuye su aumento de perfección, el que esta cosa externa, a pesar de ser aludida como una causa, pueda no ser siempre la causa de la alegría nos permite entender los errores del amor, que considera causa de su alegría a lo que quizás no lo sea. La metonimia y la metáfora son mecanismos que se aplican a todos los afectos y especialmente al amor y en el amor es esencial el papel de la imaginación, como veremos a continuación, hasta el punto que se podría decir que el amor es una construcción en la imaginación del amante que muchas veces tiene poco o nada que ver con la realidad, incluida la realidad de la cosa amada.

En efecto, si dos afectos actúan a la vez sobre la mente humana, cuando posteriormente uno de ellos afecte al alma, también el otro la afectará (E III, 14, p. 137). Esto explica que "cualquier cosa puede ser, por accidente, causa de alegría, de tristeza o de deseo" (E III, 15, p. 137), y lo mismo sucede con el amor. Lo que nos recuerda a lo que amamos suscita en nosotros también amor, (por metáfora), aunque sea solo de manera accidental y no causal. (E III, 15, corol., p.137 y E III, 16, p. 138). Si imaginamos dos cosas semejantes, una que nos produce alegría y la otra tristeza, las amaremos y odiaremos a la vez, lo que produce en nuestra mente la fluctuación del ánimo (fluctuatio animi) (E III, 17, p. 138-139). Las imágenes de las cosas pasadas nos afectan de la misma manera que las imágenes de las cosas presentes. (E III, 18, p. 139). Quien imagina que se destruye lo que ama se entristecerá y si imagina que se conserva se alegrará (E III, 19, p. 140); por el contrario, "quien imagina que se destruye aquello que odia, se alegrará (E III, 20, p. 141). Quien imagina la cosa amada afectada de alegría o de tristeza, él mismo se verá afectado de alegría o de tristeza y la intensidad de esos afectos en el amante será proporcional a la intensidad de los mismos en la cosa amada (E III, 21, p. 141), a la inversa referido a una cosa odiada (E III, 23, p. 142). De igual manera, si imaginamos que alguien afecta de alegría a una cosa que amamos seremos afectados de amor por él y por el contrario lo odiaremos si imaginamos que la afecta de tristeza, (E III, 22, p. 141), a la inversa respecto de las cosas odiadas (E III, 24, p.143).

El aspecto del amor de benevolencia se ve en la siguiente proposición: "Nos esforzamos en afirmar de nosotros y de la cosa amada todo lo que imaginamos que nos afecta o que la afecta de alegría; y, al contrario, en negar todo aquello que imaginamos que nos afecta o la afecta de tristeza" (E III, 25, p. 143); de nuevo a la inversa con las cosas odiadas (E III, 26, p.143). Espinosa expone una y otra vez su apuesta por la alegría, tanto en uno mismo como en los demás, y especialmente, en las cosas amadas, aunque su realismo le obliga 
a considerar que a veces también nos dejamos llevar por el odio. Recordamos también que todos los procesos relacionados con el amor tienen lugar en la imaginación, se trata siempre de imaginar más que de saber.

La proposición 27 destaca la importancia de la imitación de los afectos, esencial en la ética y base fundamental de la política. Según este mecanismo tenemos tendencia a amar lo que aman nuestros semejantes y a odiar lo que ellos odian. De aquí la importancia de saber definir bien los semejantes para no descarriarnos en nuestros amores y odios. Si imaginamos que alguien ama algo que nosotros amamos, este amor ajeno reforzará el nuestro; en cambio el odio hacia lo que amamos, nos produce fluctuación del ánimo, ya que somos conscientes de que algo que refuerza nuestra potencia disminuye, en cambio, la potencia de otro, por lo que vemos reducida la amabilidad de la cosa amada y no reforzada, lo que introduce en nosotros la duda acerca de la coherencia de nuestro propio amor (E III, 31, p. 147). Pero a la vez tenemos que respecto de las cosas que solo uno puede tener sucede que el que la tiene pretende impedir que los otros la posean (E III, 32, p. 148). Aparece aquí la otra cara del amor, el amor como posesión (exclusiva). Precisamente este carácter del amor hacia cosas finitas y perecederas es uno de los motivos de que Espinosa no las considere el sumo bien y busque un bien cuya posesión por parte de muchos no disminuya su atractivo, y un bien de esas características solo puede ser algo infinito y no perecedero, es decir, Dios, como luego veremos.

Otro de los aspectos esenciales del amor es la reciprocidad: "cuando amamos una cosa semejante a nosotros, nos esforzamos, cuanto podemos, en lograr que ella nos ame a su vez" (E III, 33, p. 149). De nuevo aquí, la clave está en la semejanza y en la exclusividad como se ve en la demostración: nos esforzamos en imaginar con más intensidad y dedicación a la cosa amada; si es semejante a nosotros intentamos afectarla de alegría más que a las demás cosas y nos esforzaremos en que ella, a su vez, nos considere como causa de su alegría, es decir, en que nos ame. Aquí se conjugan diversos elementos: la fijación en un solo objeto; la benevolencia hacia la cosa amada, en la que tratamos de provocar alegría; por último, queremos que reconozca nuestra benevolencia hacia ella, y que nos devuelva la alegría que provocamos en ella, otorgándonos su amor, es decir, provocando alegría en nosotros. Esta pretensión puede fracasar por varios motivos: en primer lugar, puede que, contra lo que imaginamos, no seamos capaces de aumentar su alegría; pero también puede suceder que no nos reconozca como la causa de su alegría y no se sienta, por tanto, obligada a corresponder a nuestro amor. Pero, si imaginamos que la cosa amada es afectada por nosotros, (se entiende de una manera positiva, afirmativa, alegre) entonces nos gloriamos, siendo la gloria "la alegría acompañada de la idea de una causa interna" (E III, 30, esc., 147), mientras que el amor es la alegría acompañada de la idea de una cosa externa. De nuevo aquí nuestra 
imaginación puede no ser correcta y la gloria estar injustificada, y hacer que seamos soberbios y aunque nos imaginamos que somos gratos, en realidad somos molestos para la cosa amada.

El predominio del deseo de posesión frente al de benevolencia, tan frecuente en el amor humano, produce, cuando uno imagina que la cosa amada está ligada a otro con un vínculo igual o más profundo que aquel con el que él solo la poseía, un afecto" de odio hacia la misma cosa amada y de envidia hacia ese otro" (E III, 35, p. 149) que son los celos, una fluctuación del ánimo respecto a la cosa amada y odiada a la vez junto con la envidia hacia el rival. Aquí Espinosa muestra un realismo crudo, y bastante sorprendente en alguien que se supone que era virgen y que se enamoró solo una vez de la hija de Van Enden y sin éxito, cuando nos dice: "quien imagina que la mujer que él ama, se prostituye a otro, no solo se entristecerá, porque su apetito es reprimido; sino que, además, siente aversión a ella, porque se ve forzado a unir la imagen de la cosa amada a las partes pudendas y a las excreciones de otro; a lo cual se añade, finalmente, que el celoso no es acogido por la cosa amada con el mismo semblante que solía mostrarle, por lo que también se entristecerá el amante" (E III, 35, escol., p. 150). En los celos, pues, las causas de tristeza para el amante son múltiples: el desvío de la amada que reprime su apetito al dejar de hacerle caso; el imaginarla con otro; y el captar que, al dividir sus afectos entre el amante y el rival, la amada no pone la misma cara que antes al amante. Este último motivo de tristeza se basa en que siempre queremos que las circunstancias en que gozamos de las cosas se mantengan sin cambios y cuando falta alguna de estas circunstancias iniciales nos entristecemos; en concreto si imaginamos algo que excluye la existencia de la cosa amada nos entristecemos y esta tristeza referida a la ausencia de lo que amamos (desiderium) $)^{13}$ la traduce A. Dominguez por añoranza, aludiendo al sentimiento de pérdida de dicha cosa amada.

El individuo que ama, ya que dicho amor supone un estado de alegría, no desea sino conservarlo y con un deseo tanto mayor cuanto mayor sea dicha alegría; por lo tanto, "el conato, el apetito o el deseo, que surge del odio o del amor, será mayor en proporción a dicho odio o amor" (E III, 37, p. 151). Pero cuando alguien empieza a odiar a la cosa amada hasta anular su amor por ella, la odiará más que si nunca la hubiera amado y dicho odio será tanto mayor cuanto mayor había sido antes el amor (E III, 38, p. 151), ya que ese odio no parte de la indiferencia sino del amor previo, con lo cual tiene que odiar hasta

\footnotetext{
${ }^{13}$ He tratado las relaciones entre las nociones de cupiditas y desiderium, en tanto que deseo como afirmación y deseo como carencia en: "Desiderium y Cupiditas: la esencia humana según Spinoza", $\mathrm{M}^{\mathrm{a}}$. Luisa de la Cámara y Julián Carvajal (eds): Spinoza y la Antropología en la Modernidad, Hildesheim, Georg Olms Verlag, 2017, pp. 147-156. Sobre las relaciones entre amor y deseo se puede consultar Atilano Domínguez, "Amor y deseo en Spinoza" en Eugenio Fernández y Ma Luisa de la Cámara, El gobierno de los afectos en Baruj Spinoza, Madrid, Trotta, 2007, pp. 239-261.
} 
la indiferencia y luego todavía más hasta odiar del todo. En este caso el amante tiene que reprimir más apetitos al convertir su amor en odio que alguien que nunca hubiera amado a la cosa. Quien odia a alguien se esforzará en hacerle mal, a no ser que imagine que de ahí le venga un mal todavía mayor y el que ama a alguien se esforzará en hacerle bien, como vimos antes en el amor de benevolencia (E III, 39, p. 153). Aquí bien y mal se refieren, respectivamente, a cualquier alegría, a lo que conduce a la alegría y en general, a lo que satisface un anhelo (desiderium), y a cualquier tristeza y a lo que frustra un anhelo. Si antes veíamos el carácter pasado del desiderium, traducido en añoranza, ahora vemos el carácter prospectivo del mismo, al traducirlo como anhelo. Como dijimos antes, lo definitorio del desiderium, en contraste con la cupiditas, es que no es presente, sino que se refiere bien al pasado bien al futuro; el desiderium alude a una ausencia, tanto en el tiempo como en el espacio, no está aquí y no está ahora.

Si ya vimos que la reciprocidad en el amor es siempre problemática, la reciprocidad del odio es casi automática ya que "quien imagina que es odiado por alguien, y no cree haberle dado motivo alguno de odio, le odiará a su vez "(E III, 40, p. 153). Podíamos decir incluso que, aunque le haya dado motivo de odio, le odiará igualmente, aunque ese hecho le produzca vergüenza. De todas formas, Espinosa afirma la reciprocidad también en el amor al decir que "si alguien imagina que es amado por alguno y no cree haberle dado ningún motivo para ello, le amará a su vez "(E III, 41, p. 154), mostrando agradecimiento o gratitud, sentimiento, mucho más raro que la venganza. El realismo espinosiano nos vuelve a recordar que los hombres siempre están mucho más predispuestos a la venganza que a agradecer los beneficios recibidos. Por ello quien ha hecho un beneficio a alguien, por amor o por esperanza de gloria, "se entristecerá si ve que dicho beneficio es aceptado con ánimo ingrato" (E III, 42, p. 154). De todas formas, el optimismo ontológico espinosiano que apuesta por la alegría y lo afirmativo y positivo piensa que mientras que el odio se refuerza por el odio recíproco, puede en cambio ser vencido por el amor, e incluso transformarse en amor, en un amor mayor que si no hubiera sido precedido por el odio (E III, 43 y 44, p. 155).

La relación del amante con la cosa amada es tan profunda que si alguien imagina que la cosa que ama es odiada por otra, odiará a su vez a ese otro, ya que supone que al ser odiada su amada odiará a su vez, es decir, estará triste, lo que producirá tristeza a su vez en el amante quien al unir dicha tristeza con el otro como su causa hará que lo odie (E III, 45, p.156).Ampliando esto, Espinosa dice que el amor y el odio se extiende de la cosa amada a la clase o nación a la que pertenece (E III, 46, p. 156).

Para Espinosa, nunca nos podemos abandonar completamente al odio, ya que la alegría que nos produce imaginar a alguien que odiamos afectado 
por otro mal no se produce sin la mezcla con alguna tristeza, ya que siempre el mal que afecta a un semejante nos produce tristeza (E III, 47, p. 156). Si tenemos amor y odio a la vez hacia alguien, dicho amor y odio disminuyen si imaginamos que ese alguien no ha sido la única causa de dichos amor y odio, sino que hay otra causa exterior (E III, 48, p.157). De igual manera, el amor y el odio hacia una cosa que suponemos libre es mayor que hacia una cosa, aunque sea igual a la primera, a la que consideramos necesaria, ya que si la imaginamos como libre se nos muestra por sí misma sin otras causas, mientras que si la imaginamos como necesaria la referimos a una serie de causas que coinciden con ella en la producción del efecto sobre nosotros (E III, 49, p. 158). Por ello, amamos y odiamos con más intensidad a los otros hombres que al resto de las cosas, porque los imaginamos como libres. En ese sentido, el conocimiento de las redes causales necesarias que relacionan todas las cosas, incluidos los hombres, entre sí dificulta el poder odiar a los que nos hacen mal, ya que implica que no los consideremos libres sino determinados y por lo tanto no responsables, lo que no quita para que intentemos librarnos del mal que nos producen, tanto como si los consideráramos libres.

La variedad de formas en las que las cosas exteriores afectan a los hombres es tan grande que un mismo objeto puede afectar a hombres diversos de forma distinta, y el mismo hombre puede ser afectado de diversa manera por el mismo objeto en diversos tiempos (E III, 51, p. 159), lo que explica que no todos los hombres amen las mismas cosas y que una misma cosa pueda ser amada en unas circunstancias y no amada en otra. Esta variedad entre los individuos se debe a que "cualquier afecto de cada individuo discrepa tanto del afecto de otro individuo como la esencia del uno difiere de la esencia del otro" (E III, 57, p. 166).Como estamos viendo, los afectos se componen entre si de innumerables maneras con la consecuencia de que "somos agitados de múltiples maneras por las causas exteriores y que, cual olas del mar agitadas por vientos contrarios, fluctuamos, sin conocer nuestra suerte, ni nuestro destino" (E III, 59, esc., p. 168).

En el caso concreto del amor Espinosa nos recuerda, quizás como antídoto a la idea del amor como unión con la cosa amada, que muchas veces cuando disfrutamos de la cosa amada nuestro cuerpo merced a dicho disfrute adquiere una nueva disposición que lo determina de otra forma y genera en él otras imágenes que hacen que su mente comienza a imaginar y desear otras cosas, con lo que el propio amor se resiente por su cumplimiento. Quizás por ello Espinosa nos dice que respecto del deseo no se trata tanto de satisfacerlo como de sostenerlo, es decir, se trata de pasar del deseo como desiderium al deseo como cupiditas, ya que la diferencia entre desiderium y cupiditas sería que el primero es necesariamente transitivo, es siempre 'deseo de', en el sentido de conciencia de una carencia, frustración derivada de esa carencia y añoranza 
y/o anhelo de dicha cosa ausente, mientras que el segundo es intransitivo, no está referido a ningún objeto externo y es una acción que conserva y expande la potencia del individuo. La estrategia de Espinosa consiste en liberar el deseo de su objeto intencional, rompiendo la cadena que nos une al objeto amado, de esta manera nos liberamos de él y de la esperanza ligada a su obtención y obtenemos una alegría (laetitia) constante y estable. El amor basado en la cupiditas afirma la laetitia como una pasión activa y la libera de la fortuna y del encadenamiento temporal de los eventos; mientras que el desiderium es un delirio que se concentra en un solo objeto sobre el que proyecta todo tipo de perfecciones, generalmente inexistentes, el amor debido a la cupiditas es potencia de la mente y puede ir hasta el amor intelectual a Dios, ya que relaciona todos los objetos entre sí en el seno de la Substancia, conoce las redes causales necesarias en las que están inmersos y de ese conocimiento extrae un amor intelectual y una felicidad supremos ${ }^{14}$.

Espinosa frente a la mayor parte de la tradición no considera que los afectos sean sólo pasiones, es decir que seamos solo pasivos por su causa; por el contrario, nuestro autor piensa que hay afectos activos, afectos asociados al hombre en cuanto éste es activo. Ahora bien, los únicos afectos que pueden ser activos son los relacionados con el deseo y la alegría, pero no los que producen tristeza porque la actuación humana está asociada a la concepción de ideas adecuadas, es decir, ideas que nos tienen a nosotros mismos como su causa principal y la tristeza disminuye o reprime la potencia de pensar de nuestra mente (E III, 58 y 59, p.167). Todas las acciones que se siguen de los afectos derivados de la mente en cuanto esta entiende las refiere nuestro autor a la Fortaleza (Fortitudo) a la que divide en Firmeza (Animositas) y Generosidad (Generositas), siendo la primera el deseo de conservar su ser según el solo dictamen de la razón, y la segunda el esfuerzo por ayudar a los demás hombres y unirse a ellos mediante lazos de amistad, según el solo dictamen de la razón (E III, 59, esc., p. 168). Como vemos, el paso de la pasividad a la actividad ha supuesto el paso de la imaginación a la razón, asociada a la posibilidad de concebir ideas adecuadas; dejamos, pues, el uso de la imaginación, que volverá a tener un papel central en el libro V asociada al amor ya no humano sino divino.

Una vez analizada en el libro III la naturaleza y el origen de los afectos nuestro autor pasa en el libro IV a considerar la fuerza de dichos afectos que causa la esclavitud humana, para concluir en el libro V con la afirmación de la potencia del entendimiento que posibilita la libertad humana, libertad en la que jugará un papel central el amor intelectual hacia Dios. Este proceso ascendente es a la vez cognoscitivo, ya que se pasa paulatinamente de la ignorancia a la sabiduría, y afectivo, ya que se pasa de la esclavitud a la libertad. El amor

${ }^{14}$ Cf. Mi trabajo sobre Desiderium y Cupiditas citado antes.

Araucaria. Revista Iberoamericana de Filosofía, Política y Humanidades, año 20, n 39. Primer semestre de 2018. Pp. 271-296. ISSN 1575-6823 e-ISSN 2340-2199 doi: 10.12795/araucaria.2018.i39.13 
que en su faceta meramente humana es muchas veces causa de esclavitud y de ignorancia, cuando adquiere un carácter divino, no solo porque su objeto es Dios sino porque su ejercicio diviniza al amante, es a la vez un medio para la liberación y la libertad misma que culmina el proceso. De ser un estado de enajenación centrado de forma ilusoria en un solo objeto, el amor pasional, se pasa a un estado de libertad absoluta, debido al amor intelectual de Dios, en el que el amante se inserta en el conjunto de la realidad mediante el conocimiento y el amor y adquiere de esta manera la felicidad suprema, la beatitud o la gloria, ya no meramente imaginaria sino plenamente racional.

Precisamente es el sometimiento a las pasiones lo que enfrenta a los hombres entre sí, mientras que la vida bajo la guía de la razón hace que concuerden siempre y necesariamente en naturaleza los individuos (E IV, 34 y 35, pp. 204-205). Espinosa plantea el caso de dos individuos que aman la misma cosa y uno la tiene y el otro no. La causa de su discrepancia reside en que en relación a este caso presentan distinta naturaleza: el que posee la cosa se encuentra afectado de alegría y, en cambio, el que no la tiene se encuentra afectado de tristeza y, es ese sentido, son contrarios entre si (E IV, 34, esc., p. 204).

Al final del libro IV vemos dibujarse el modelo de individuo humano que nos muestra nuestro autor definido como 'hombre fuerte': es alguien que "no tiene odio a nadie, no se irrita contra nadie, no envidia, ni se indigna, ni desprecia a nadie, y no es en absoluto soberbio". La actuación de un individuo tal parte de la idea de que "el odio deber ser vencido con el amor y que todo aquel que se guía por la razón, desea para otros el bien que desea para sí” y su objetivo último consiste en "concebir las cosas como son en sí y en remover los obstáculos del verdadero conocimiento" (E IV, 73, esc., p. 232). Aquí vemos el papel central del amor y la generosidad, así como la importancia del conocimiento en el proceso de consecución del sumo bien por parte de los individuos fuertes y sabios.

Para Espinosa no se trata de consumar el amor sino más bien de depotenciar su poder sobre nosotros. Igual que con el resto de emociones o afectos del ánimo, esta depotenciación la podemos lograr separando dicho afecto del pensamiento de la causa externa que la acompaña y uniéndolo a otros pensamientos y considerando la cosa amada no en el tiempo en que se da sino desde el punto de vista de la eternidad. De esta manera se destruye tanto el amor como el odio hacia la causa exterior que constituye su objeto como las fluctuaciones del ánimo que surgen de estos afectos (E V, 2, p. 246). Por otra parte, un afecto que es pasión, es decir una idea confusa, deja de serlo cuando formamos de él una idea clara y distinta (E V, 3, p. 247). Esto se aplica también al amor y, por lo tanto, el conocimiento del amor hace que se sujete a nuestra potestad y que suframos menos por su causa. 
El optimismo espinosiano y su confianza en la potencia del entendimiento le permite afirmar que "no hay ninguna afección del cuerpo, de la que no podamos formar un concepto claro y distinto" y, por lo tanto, tampoco hay ningún afecto, ya que los afectos son las ideas de las afecciones, del que no podamos formar un concepto claro y distinto, y de esta manera reducir su poder sobre nosotros. (E V, 4, p. 247). Los afectos pueden ser pasiones cuando surgen de ideas inadecuadas, mientras que pueden ser virtudes cuando surgen de ideas adecuadas, o sea se originan a partir de un conocimiento verdadero y racional. La depotenciación de los afectos, y especialmente del amor, se puede lograr también refiriendo a varias y diversas causas en lugar de a una sola. El carácter nocivo del amor, y en general de los afectos, se debe principalmente a la fijación en una sola cosa, lo que impide que el alma pueda pensar otras cosas y la empobrece (E V, 8, p. 250).

Pero, como siempre, el optimismo de Espinosa se ve contrabalanceado por su realismo, ya que también afirma que "la capacidad de ordenar y concatenar las afecciones según un orden relativo al entendimiento" depende de que no estemos sometidos a conflictos de afectos contrarios a nuestra naturaleza que impidan que nuestra alma entienda (E V, 10, p. 250-251). Se trata, pues, como nos recuerda Bodei ${ }^{15}$, de pasar "de las fluctuaciones a las transiciones", es decir de conseguir a través del conocimiento no tanto suprimir las pasiones como transfigurarlas en afectos activos, al someterlas a una transitio que las lleva a un proceso ascendente de perfección y felicidad. Esta transformación de las pasiones conlleva que se pasa de la primacía de las causas exteriores a la primacía del conocimiento adecuado de las mismas. Pero se trata también de ampliar el campo de nuestra atención, abriéndola hacia más cosas, y tendencialmente hacia todas las cosas en su conjunto, convirtiendo el amor centrado en un solo objeto en el amor erga Deum ${ }^{16}$.

Para concluir este repaso de la noción de amor humano en Espinosa recordamos que para nuestro autor, el amor libidinoso (praeterea meretricius), en tanto que "deseo de engendrar que nace de la belleza" y en general todos los amores que no tengan su origen en la libertad del ánimo (animi) se transforman fácilmente en odio y además pueden degenerar en un delirio (E IV Apéndice cap. 19, p. 236). Respecto del matrimonio el mismo es concorde con la razón si su objetivo no es solo la belleza, sino el amor de procrear hijos y educarlos y tiene también por causa la libertad de ánimo (E IV, Apéndice cap.20, p. 236). Aquí concluye nuestra reflexión sobre el amor humano y pasamos al amor hacia Dios en sus diferentes modalidades que es el objeto del libro $\mathrm{V}$ y conclusivo de la Etica.

\footnotetext{
${ }^{15}$ Cf. Remo Bodei, "Gramática del amor" en Una geometría de las pasiones, Barcelona, Muchnik Eds., 1995, pp. 417-481.

${ }^{16}$ Cf. Pierre Macheray, Introduction a l'Ethique de Spinoza.La cinquieme partie. Les voies de la libération, París, PUF, 1994, p. 76.
} 


\section{Amor divino}

Hemos visto que el amor a las cosas perecederas por su inestabilidad y limitación no puede constituir el sumo bien que el hombre busca. Por ello Espinosa dirige la mirada hacia Dios, pero hay que entender bien qué quiere decir con esta noción nuestro autor. Si se entiende en un sentido literal, el libro $\mathrm{V}$ de la Etica no se distingue casi en nada de la tradicional apologética cristiana del desprecio del mundo, tan en boga en el barroco que en sus maravillosas naturalezas muertas, que, por un lado, exhiben la magnificencia de las obras humanas, pero al mismo tiempo las presentan como efímeras y sometidas al implacable deterioro a las que el tiempo las somete. Las frutas más sabrosas siempre tienen un gusano y detrás de la exuberancia de la carne se entrevé el poder inexorable de la decadencia y la muerte. Sólo la postergación de dichos bienes aparentes en beneficio de un bien verdadero puede concedernos la verdadera felicidad. Espinosa no cae en esta rúbrica ya que para él Dios no es el Dios personal judeo-cristiano, sino el conjunto de las leyes naturales que expresan el poder vivificante que hay detrás de las cosas finitas, la natura naturans que sostiene y mantiene la natura naturata o conjunto de las cosas finitas ${ }^{17}$.

Dado que la mente puede formar de cada afección del cuerpo un concepto claro y distinto, como ya hemos visto, también puede, por lo tanto, referir dichas afecciones a la idea de Dios (E V, 14, p. 253), con lo que dichas las ideas de dichas afecciones dejan de estar aisladas y se concatenan entre sí en el seno de las leyes naturales, que es la expresión de la idea de Dios. El paralelismo entre el conocimiento y el amor se expone en la siguiente proposición que afirma que: "quien se conoce clara y distintamente a sí mismo y a sus afectos, ama a Dios, y tanto más cuanto más se entiende a sí mismo y a sus afectos" (E V, 15, p. 253). Cuando el conocimiento de sí mismo es máximo, entonces el amor a Dios ocupa al máximo el alma (E V, 16, p. 254). De todas formas, el que el Dios de Espinosa no sea un Dios personal (para evitar la caída en el antropomorfismo ferozmente criticado en la Etica y el Tratado Teológico Político) hace que "Dios esté exento de pasiones y no es afectado de ningún afecto de alegría o de tristeza (E V, 17, p. 254), lo que le impide amar u odiar a nadie, si tomamos la idea de amor o de odio con propiedad.

De igual manera, "nadie puede odiar a Dios" (E V, 18, p. 254), ya que, dado que la idea de Dios que tenemos es perfecta y adecuada, al contemplar a Dios actuamos, no estamos sometidos a pasiones, y por lo tanto no podemos experimentar ninguna tristeza asociada a la idea de Dios, y, por lo mismo,

${ }^{17}$ Alexandre Matheron, lo define como "esta actividad productiva inmanente a las cosas, esta productividad infinita e inagotable de toda la naturaleza" en su "Préface" al libro de Antonio Negri, L'anomalie sauvage, París, PUF, 1982, p. 2

Araucaria. Revista Iberoamericana de Filosofía, Política y Humanidades, año 20, n 39. Primer semestre de 2018. Pp. 271-296. ISSN 1575-6823 e-ISSN 2340-2199 doi: 10.12795/araucaria.2018.i39.13 
nunca podemos odiar a Dios. Lo que no es óbice para que Dios pueda ser causa de las tristezas que sufrimos, como es causa de todo lo que existe, en tanto que existe, aunque al entender las cusas de dichas tristezas sufridas por nosotros experimentamos alegría y por ello, "en la medida en que entendemos que Dios es causa de la tristeza, nos alegramos "(E V, 18, esc., pp. 254-255). Dado que Dios, propiamente, no puede amar u odiar a nadie, "quien ama a Dios, no puede esforzarse por que Dios le ame a su vez” (E V, 19, p. 255).

Estas afirmaciones de nuestro autor le sitúan claramente fuera del ordo amoris cristiano, basado en una corriente de amor mutuo entre el Creador y las criaturas. Hay una falta de reciprocidad entre Dios y las cosas finitas, especialmente los hombres, ya que estos le aman, pero no pueden exigir que él los ame a su vez. La gran cadena del ser, de origen neoplatónico y cristiano, se rompe en Espinosa: Dios recibe el amor de los unos, pero no lo devuelve, ya que eso supondría que es un ser personal, sometido a pasiones, cosa que Espinosa descarta de forma radical. En Espinosa, la relación entre Dios y las cosas finitas es de una causalidad inmanente, no creacionista, no emanatista, y tampoco de una mera deducción geométrica sino una 'procesión inmanente' de la substancia a los modos, de la natura naturans a la natura naturata, lo que imposibilita completamente considerar a Dios una persona ${ }^{18}$.

Que el amor hacia Dios es el sumo bien se ve también porque puede y debe ser compartido por todos los hombres y nadie lo puede usufructar en exclusividad, lo que hace que dicho amor no pueda ser "mancillado por un afecto de envidia ni de celos", sino que es más perfecto cuanto más hombres imaginamos unidos por dicho vínculo del amor a Dios. (E V, 20, p. 255). Mientras que la mayor parte de los infortunios del alma nos vienen de que otorgamos un amor excesivo a cosas sometidas a variación continua y de las que nunca podemos ser completamente dueños, el amor hacia una cosa inmutable y eterna, Dios mismo, basado en un conocimiento claro y distinto y en especial en el conocimiento correspondiente al tercer género, nos permite controlar los afectos y aunque no los podamos eliminar nunca del todo, contra los estoicos y Descartes, si podemos al menos hacer que dichos afectos constituyan una parte mínima del alma ${ }^{19}$. El amor hacia Dios (amor erga Deum) es el resultado de un proceso de la mente que tiende hacia la racionalidad, lo que hace que se lo pueda considerar como "el sumo bien que podemos apetecer según el dictamen de la razón” (E V, 2, p. 255).

${ }^{18}$ Cf.Gabriel Huan, Le Dieu de Spinoza, París, Alcan, 1914, p. 304.

19 En la inevitabilidad de las pasiones nuestro autor coincide con Arnold Geulincx, un cartesiano que sin embargo si defiende la voluntad libre, a pesar de considerar que la aceptación de lo que nos pasa es condición de la beatitud, una beatitud asociada al amor a Dios en lugar del amor a sí mismo. (Cf. Han van Ruler, "Le sage et l'amour de Dieu. Conceptions de la béatitude d' Erasme á Spinoza" en Severio Ansaldi (dir.) Spinoza et la renaissance, París, PUPS, 2007, pp. 57-80). 
De todas formas, y de nuevo contra la opinión dominante que separa de forma radical a Dios de las criaturas, para Espinosa," cuanto más entendemos las cosas singulares, más entendemos a Dios"(E V, 24, p. 258) ya que Dios no es solo causa de la existencia de las cosas sino también de su esencia (E, I, 25, p. 59) y el conocimiento de los efectos nos lleva al conocimiento de la causa, al menos cuando esta causa es inmanente. El supremo esfuerzo del alma es entender las cosas a través del tercer género de conocimiento $(E \mathrm{~V}, 25, \mathrm{p}$. 258), es decir, del que procede "de la idea adecuada de algunos atributos de Dios al conocimiento adecuado de la esencia de las cosas", y no el que opera mediante nociones comunes, o segundo género de conocimiento o razón. Dicho conocimiento de tercer género hace que cuanto más apta sea la mente para el mismo, más desea utilizarlo (E V, 26, p. 259). Y el conocimiento del tercer género produce en el alma la mayor tranquilidad que puede darse (E $\mathrm{V}, 27$, p. 259). El esfuerzo por conocer las cosas mediante el tercer género de conocimiento no puede surgir del primero pero sí del segundo género ( $\mathrm{E}$ V 28, p. 259).

El conocimiento de Dios por parte de nuestra mente, conocimiento que incluye el conocimiento de que dicha mente está en Dios y se concibe por Dios, se desprende del conocimiento que la mente tiene de sí misma y de su cuerpo "bajo una especie de eternidad" (E V, 30, p. 260). El tercer género de conocimiento tiene la mente como causa formal en tanto que dicha mente es eterna ( $\mathrm{E} V, 31$, p. 261), ya que, al ser nuestra mente eterna, tiene un conocimiento adecuado de Dios y por lo tanto tiene un conocimiento adecuado de todas las cosas que se siguen de este conocimiento de Dios, es decir, un conocimiento de tercer género. A continuación, Espinosa establece una relación entre el conocimiento de tercer género y un gozo derivado de dicho conocimiento que se ve acompañado de la idea de Dios como causa (E V, 32, p. 262). En este nivel, pues, el conocimiento produce gozo, es decir, el tercer género de conocimiento produce necesariamente el amor intelectual de Dios, es decir, una alegría acompañada de la idea de Dios como causa, o sea, un amor de Dios, amor no derivado de que consideremos a Dios como presente, sino de que lo consideramos eterno: "el amor intelectual de Dios, que surge del tercer género de conocimiento, es eterno" (E V, 33, p. 262). Y además, ningún otro amor lo es (E V, 34, corolario, p. 263).

A continuación, Espinosa afirma que: "Dios se ama a si mismo con un amor intelectual infinito" (E V, 35, p. 263), lo que parece contradecir la idea expuesto antes de que Dios no podía amar ni odiar ${ }^{20}$. Este amor a sí mismo se deriva de que Dios es absolutamente infinito y dicha perfección al acompañarse de la idea de sí mismo, en tanto que causa de sí, es lo que ha denominado amor

${ }^{20}$ Suhamy plantea tres paradojas de este tipo de amor: no es propiamente una alegría, no tiene una causa exterior, y su objeto no está presente. (Cf. Ariel Suhamy, op. cit., p. 80)

Araucaria. Revista Iberoamericana de Filosofía, Política y Humanidades, año 20, no 39. Primer semestre de 2018. Pp. 271-296. ISSN 1575-6823 e-ISSN 2340-2199 doi: 10.12795/araucaria.2018.i39.13 
intelectual de Dios. En Dios no hay alegría, porque no hay aumento posible de potencia, pero si hay perfección y esta perfección unida a la idea de su causa es lo que se denomina amor, en este caso, amor intelectual de Dios, un amor que poco tiene que ver con el amor que despliegan los humanos. Este amor de Dios por sí mismo es infinito y el amor intelectual que cada mente tiene respecto de Dios es una parte de este amor infinito, es el mismo amor con el que Dios se ama a sí mismo, pero no en cuanto infinito sino "en cuanto puede explicarse por la esencia del alma humana, considerada bajo una especie de eternidad" (E V, 36, p. 263). El amor intelectual de Dios por sí mismo es la suma de todos los amores intelectuales que las mentes de los hombres tienen respecto a Dios, en tanto que dichas mentes son consideradas bajo una especie de eternidad; de igual maneara que el conocimiento que Dios tiene de sí mismo es la suma de los conocimientos que nuestros entendimientos tienen de Dios ${ }^{21}$.

De nuevo vemos, que Dios no se puede entender sin el conjunto de las cosas finitas, de las que constituye su causa inmanente, o fuente de la fuerza vivificante de las mismas. Como corolario de lo anterior Espinosa dice que "Dios, en cuanto que se ama a sí mismo, ama a los hombres "y que "el amor de Dios a los hombres y el amor intelectual del alma a Dios es una y la misma cosa" (E V, 36, Corolario, p. 264). Aquí parece que se restablece el círculo neoplatónico del amor que baja de Dios a las cosas y retorna de las cosas a Dios, pero la apuesta espinosiana por la inmanencia impide esta interpretación, porque Dios al amarse a sí mismo ama necesariamente a los hombres, ya que Dios no es nada más que la causa inmanente de los hombres y del resto de las cosas, o sea las cosas mismas vistas desde el punto de vista de la fuerza vivificante que las sostiene. Por otra parte, el amor que Dios tiene por cada hombre es el mismo amor que Dios se tiene a sí mismo, considerado parcialmente y no en su totalidad, mientras que el amor que la mente tiene a Dios es el amor a la totalidad de las cosas en su aspecto creador y vivificante. Es el mismo tipo de amor, pero no el mismo amor, ya en un caso es amor a una parte del todo, es decir a una cosa particular, y en el otro es amor al conjunto.

Por otra parte, como ya dijimos antes, el amor de Dios se basa no en la alegría sino en la perfección, o sea que no es un amor propiamente dicho, mientras que el amor del hombre hacia Dios si se basa en la alegría, ya que dicho amor genera un aumento de potencia y de perfección en dicho hombre, es decir, alegría. Este amor intelectual a Dios no tiene nada en la naturaleza que le sea contrario o que lo pueda suprimir, ya que dicho amor intelectual a Dios se sigue necesariamente de la naturaleza del alma que lo experimenta, la cual en tanto que es una verdad eterna es considerada a través de la naturaleza de Dios , y no puede ser falsa(E V, 37, p. 264).Para Espinosa el amor constante y eterno a Dios, que, como hemos visto, coincide con el amor de Dios a los

${ }^{21}$ Cf. Huan, op. cit, p. 232.

Araucaria. Revista Iberoamericana de Filosofía, Política y Humanidades, año 20, n 39. Primer semestre de 2018. Pp. 271-296. ISSN 1575-6823 e-ISSN 2340-2199 doi: 10.12795/araucaria.2018.i39.13 
hombres, es en lo que consiste nuestra salvación, felicidad o libertad y dicho amor o felicidad puede ser llamado gloria. Este amor ya no es una pasión sino una acción, ya que se explica completamente por la idea de Dios y además dicha idea de Dios es su causa adecuada ${ }^{22}$.

Como vemos, pues, la felicidad no se desprende del amor, sino que coincide con él, de igual manera que posteriormente Espinosa nos dirá que la felicidad no es el premio de la virtud sino la virtud misma; aquí nuestro autor retoma la inspiración estoica para identificar virtud y felicidad. De ahí se deriva que no es la represión de la concupiscencia lo que produce la virtud y por tanto la felicidad, sino, por el contrario, al gozar de la virtud, no solo alcanzamos la felicidad, sino que eso es lo que nos permite controlar, al menos en parte, nunca de forma total, la concupiscencia (E V 42, p. 268). La gloria, pues, en tanto que coincide con el amor intelectual a Dios, se vive por parte del alma como tranquilidad del ánimo. Una tranquilidad que es una alegría acompañada de la idea de sí mismo y que se puede aplicar, tanto a Dios, aunque en este caso la noción de alegría el propio Espinosa es consciente de que no es muy propia y por esos dice" permítaseme emplear todavía la palabra", como al alma. En el escolio de la proposición 36 Espinosa recalca que el conocimiento de las cosas singulares es más perfecto cuando se lleva a cabo a través del tercer género de conocimiento o conocimiento intuitivo que cuando es el resultado del conocimiento de segundo género, o conocimiento universal, ya que el conocimiento intuitivo es un conocimiento de las esencia de las cosas singulares, mientras que el conocimiento racional o de segundo género, es un conocimiento universal, obtenido a partir de las nociones comunes a las distintas cosas singulares, es un conocimiento más indirecto y abstracto.

Ya en libro II de la Etica se afirma que una de las ventajas de la doctrina allí defendida para la práctica de la vida consiste en que el ser conscientes de que "obramos por el solo beneplácito de Dios y que somos partícipes de la divina naturaleza, y tanto más cuanto más perfectas acciones realizamos y cuanto más y más entendemos a Dios" produce en nuestro ánimo (animus) "una quietud completa" y nos enseña que nuestra suma felicidad o beatitud coincide con el "solo conocimiento de Dios", conocimiento que nos induce a hacer solamente "lo que el amor y la piedad nos aconsejan". (E II, 49, escolio, p. 120).

La mayor felicidad para el individuo consiste en unirse mediante el amor intelectual a Dios, pero esta noción también encierra una paradoja ${ }^{23}$ ya que el

${ }^{22}$ Cf. Yitzhak Y. Melamed, "Spinoza's Amor Dei Intellectualis".

${ }^{23}$ Mientras que Maimónides era renuente a aplicar a Dios cualquier afecto, incluido el amor, Gersónides y Crescas si hablan del amor divino. (Cf. Yitzhak Y. Melamed, "Spinoza's Amor Dei Intellectualis", disponible en internet, en Academia.edu). Jean Préposiet ha planteado las dos paradojas del amor dei intellectualis, la conciliación entre un dios impersonal e impasible y un Dios que se ama a sí mismo y al hombre y un amor que como alegre tendría que suponer aumento de perfección y la beatitud en que consiste el amor dei intellectualis que es la felicidad suprema sin posible aumento. (Cf. Jean Préposiet, “Amor dei intellectualis" en Atilano Domínguez, La Etica de Spinoza. Fundamentos y 
amor es una pasión, lo que supone una dependencia respecto de la cosa amada y Espinosa defiende en el libro V de la Etica a la vez que Dios es el objeto del amor del hombre pero que no ama a su vez al hombre y en otro sitio que ese amor intelectual de Dios es reversible y dios ama a su vez al hombre. Esta paradoja ha conducido a varios actores a defender que el amor intelectual a Dios no es un amor propiamente dicho sino otro tipo de relación activa con $\operatorname{Dios}^{24}$, sería un estado emotivo paralelo al tercer género de conocimiento del que dimana, estado emotivo producido por la comprensión intelectiva de la realidad substancial. De igual manera la beatitud no es un afecto, porque es posesión y no transición de un estado a otro ${ }^{25}$.

En relación a esta cuestión Matheron concibe el amor intelectual de Dios como la parte eterna del amor erga Deum ${ }^{26}$, de forma paralela a la consideración del entendimiento como la parte eterna de la mente. El autor francés dice que los afectos suponen una transición, pero que a la vez su realidad se contiene y se integra en su estado final; con lo cual toda alegría, en cuanto afecto que es presenta un aspecto de 'paso' y un aspecto de 'resultado del paso'. Esta dualidad se aplica también al amor erga Deum. El amor dei intellectualis no produce una alegría, en tanto que transición, sino la beatitud que no es paso a una perfección mayor sino la perfección suma, es la llegada, el resultado del proceso. Nuestro autor establece una proporción: la alegría es al amor erga Deum como la beatitudo es al amor dei intellectualis, y como la beatitud no es una alegría, tampoco el amor dei intellectualis es un amor, propiamente dicho.

\section{Conclusiones}

Tenemos, pues, cinco formas posibles de amor obtenidas mediante la combinación de los tres géneros de conocimiento y los dos tipos de entes posibles: la Substancia y los modos finitos, o Dios y las criaturas. En los tres casos de amor humano ${ }^{27}$ pasamos del amor pasional o amor imaginario por un objeto que se absolutiza y aísla generando una especie de delirio; al amor racional basado en las nociones comunes que es consciente de que el amante

significados, Ciudad Real, Ediciones de la Uni. Castilla La Mancha, 1992, pp.483-492).

${ }_{24}$ Cf.Marcos Travaglia, "Contento de Dios: un aporte a la comprensión del amor Dei intellectualis de Baruch Spinoza”, Controvérsia, vol. 12, n² 2, São Leopoldo, mayo-ago. 2016, pp. 97-103.

${ }^{25}$ Cf. Juan Diego Moya, "El amor intellectualis dei spinociano", Revista de Filosofia Univ. Costa Rica, XXXIII (81), 1995, pp.163-170., disponible en internet.

${ }^{26}$ Cf. Alexandre Matheron, "L'amour intellectuel de Dieu, partie éternelle de l'amor erga Deum" en Études sur Spinoza et les philosophies de l'âge classique, Lyon, ENS, 2011, pp. 709-725.

${ }^{27}$ Cf. Lucia Gerszenzón, "El amor pasional en la Etica de Spinoza", Ideas. Revista de Filosofía moderna y contemporánea, $\mathrm{n}^{\mathrm{o}} 3$, otoño 2016, pp. 110-134, disponible en Google Books. 
y la cosa amada comparten naturaleza; aunque si nos apoyamos en el $\mathrm{TB}^{28}$ parecería ser que no es posible basar el amor solo en la razón y en lo común ya que este segundo género de conocimiento no permite el conocimiento directo e inmediato de la cosa amada sino solo lo que tiene en común con nosotros y además de forma indirecta; para concluir por fin en el amor basado en la ciencia intuitiva en el que el amante es consciente de que tanto él mismo como la cosa amada son ambos modos finitos de la Substancia infinita en las que tienen su ser y en la que pueden ser concebidos, Dios, es decir, son partes de un orden necesario y universal; esta consciencia permite referir el amor a la cosa amada a la idea de Dios y concebirlo pues como una parte finita del infinito amor con el que Dios se ama a si mismo; en este nivel el amor a una cosa finita es amor a Dios, es decir a la Naturaleza en tanto que se expresa a través de dicha $\operatorname{cosa}^{29}$.

Respecto del amor divino, se ha podido entender el amor erga deum, en tanto que amor no dirigido a una persona, ni sometido a las fluctuaciones del ánimo, sino inalterable, como el resultado del movimiento demostrativo que constituye el conocimiento deductivo o racional, es decir, el de segundo género, y como resultado de la presencia de las nociones comunes que remite de forma indirecta a Dios que no puede ser considerado desde el punto de vista de la presencia sino sólo desde el punto de vista de la eternidad; mientras que el amor intelectual a Dios es el amor basado en el tercer género, es decir en la ciencia intuitiva. El amor a Dios no es, en Espinosa, el ejercicio solitario de un asceta sino el resultado de una práctica colectiva que sirve de base a la unidad de la sociedad. La idea racional de Dios es la clave de la vida afectiva de los individuos en tanto que vive en sociedad ${ }^{30}$.

${ }^{28}$ TB II, cap. III, 4, p. 104. Cf. Chantal Jaquet, 'L'essence de l'amour dans les Dialogues d'amour de Leon L'Hébreu et dans le Court Traité" en Severio Ansaldi (dir.) Spinoza et la renaissance, París, PUPS, 2007, p. 50.

${ }^{29}$ Cf. Jacqueline Lagrée, "Spinoza et l'amour intellectuel du prochain" en Chantal Jaquet, Pascal Séverac, Ariel Suhamy, Spinoza, philosophe de l'amour, Saint-Etienne, Publications de 1'Université de Saint- Etienne, 2005, pp. 97-111).

${ }^{30}$ Cf. Roberto Cicarelli, "L' eternitá nella scienza intuitiva en el diritto della moltitudini", en Filippo Del Lucchese y Vittorio Morfino (eds.), Sulla scienza intuitiva in Spinoza, Milán, Ed. Ghibli 2003, pp. 45-46.

También Macheray, op. cit, pp. 101-102.

Araucaria. Revista Iberoamericana de Filosofía, Política y Humanidades, año 20, n 39. Primer semestre de 2018 Pp. 271-296. ISSN 1575-6823 e-ISSN 2340-2199 doi: 10.12795/araucaria.2018.i39.13 


\section{Referencias bibliográficas:}

Ansaldi, Saverio, "Un nouvel art d'aimer. Descartes, Léon 1'Hébreu et Spinoza" en Chantal Jaquet, Pascal Séverac, Ariel Suhamy, Spinoza, philosophe de l'amour, Saint-Etienne, Publications de l'Université de Saint- Etienne, 2005.

Bodei, Remo, "Gramática del amor" en Una geometría de las pasiones, Barcelona, Muchnik Eds., 1995, pp. 417-481.

Bodei, Remo, Ordo amoris. Conflictos terrenos y felicidad terrestre, Valladolid, Cuatro ediciones, 1998.

Brunschvig, Leon, "Le platonisme de Spinoza" en Cronicum Spinozanum, tomo III, Amsterdam,1923, pp.253-268.

Cicarelli, Roberto, 'L' eternitá nella scienza intuitiva en el diritto della moltitudini”, en Filippo Del Lucchese y Vittorio Morfino (eds.), Sulla scienza intuitiva in Spinoza, Milán, Ed. Ghibli, 2003.

Descartes, René, Passions de l'âme, II, artículo LXIX, París, 1649.

Descartes, René, Correspondencia con Isabel de Bohemia y otras cartas, Barcelona, Alba Editorial, 1999.

Domínguez, Atilano, "Amor y deseo en Spinoza” en Eugenio Fernández y Ma Luisa de la Cámara, El gobierno de los afectos en Baruj Spinoza, Madrid, Trotta, 2007, pp. 239-261.

Gebhardt, Carl, "Spinoza und der Platonismus" en Cronicum Spinozanum, tomo I, Amsterdam,1921, pp. 178-234.

Gerszenzón, Lucia, “El amor pasional en la Etica de Spinoza”, Ideas. Revista de Filosofía moderna y contemporánea, no 3, otoño 2016, pp. 110- 134.

Hebreo, León, Diálogos de amor, Madrid, Alianza, 2002.

Huan, Gabriel, Le Dieu de Spinoza, París, Alcan, 1914.

Jaquet, Chantal, 'L'essence de l'amour dans les Dialogues d'amour de Leon L'Hébreu et dans le Court Traité" en Severio Ansaldi (dir.), Spinoza et la renaissance, París, PUPS, 2007.

Lagrée, Jacqueline, "Spinoza et l'amour intellectuel du prochain" en Chantal Jaquet, Pascal Séverac, Ariel Suhamy, Spinoza, philosophe de l'amour, Saint-Etienne, Publications de l'Université de Saint- Etienne, 2005.

Macheray, Pierre, Introduction a l'Ethique de Spinoza.La cinquieme partie. Les voies de la libération, París, PUF, 1994.

Martínez, Francisco José, "Desiderium y Cupiditas: la esencia humana según Spinoza", Ma Luisa de la Cámara y Julián Carvajal (eds): Spinoza y la Antropología en la Modernidad, HIldesheim , Georg Olms Verlag 2017, pp. 147-156. 
Matheron, Alexandre, 'L'amour intellectuel de Dieu, partie éternelle de l'amor erga Deum" en Études sur Spinoza et les philosophies de l'âge classique, Lyon, ENS, 2011, pp. 709-725.

Moreau, Pierre François, "L'amour dans le Traité de la réforme de l'entendement" en Chantal Jaquet, Pascal Séverac, Ariel Suhamy, Spinoza, philosophe de l'amour, Saint-Etienne, Publications de l'Université de Saint- Etienne, 2005.

Moya, Juan Diego, "El amor intellectualis dei spinociano", Revista de Filosofía Univ. Costa Rica, XXXIII (81), 1995, pp.163-170.

Negri, Antonio, L'anomalie sauvage, París, PUF ,1982.

Pinheiro, Ulysses, "A presença do neoplatonismo de Leão Hebreu na Etica de Spinoza", Kléos no 19, 2015, pp. 227-246.

Préposiet, Bernard, "La premiére 'Ethique'. Méthode et perspectives" en Bernard Préposiet, L’inmanence et le salut. Regards spinozistas, Paris, Kimé, 2000.

Préposiet, Jean, "Amor dei intellectualis" en Atilano Domínguez, La Etica de Spinoza. Fundamentos y significados, Ciudad Real, Ediciones de la Univ. Castilla La Mancha 1992, pp.483-492.

Sabiuda, Ramón, Tratado del amor de las criaturas, Madrid, Tecnos, 1998.

Scheler, Max, Ordo amoris, Madrid, Caparrós Editores, 1996.

Spinoza, Baruj, Tratado de la reforma del entendimiento/Principios de filosofía de Descartes/ Pensamientos metafísicos, Madrid, Alianza, 1988, TRE.

Spinoza, Baruj, Tratado Breve, Madrid, Alianza, 1990, TB.

Spinoza, Baruj, Etica demostrada según el orden geométrico, Trotta, Madrid, 2000, E.

Suhamy, Ariel, "Essence, propriété et espéces d'amour dans l'Ethique" en Chantal Jaquet, Pascal Séverac, Ariel Suhamy, Spinoza, philosophe de l'amour, Saint-Etienne, Publications de l'Université de Saint- Etienne, 2005.

Travaglia, Marcos, "Contento de Dios: un aporte a la comprensión del amor Dei intellectualis de Baruch Spinoza", Controvérsia, vol. 12, n 2, São Leopoldo, mayo-ago. 2016, pp. 97-103.

Van Ruler, Han, "Le sage et l'amour de Dieu. Conceptions de la béatitude d'Erasme á Spinoza” en Severio Ansaldi (dir.) Spinoza et la renaissance, París, PUPS, 2007, pp. 57-80. 